\title{
Contribution of Apiculture in Social and Economic Development of Nigeria
}

\author{
*AGBOOLA, IS; GEORGE- ONAHO, JA; ETE, JA; AYANDOKUN, AE \\ Forest Protection and Conservation Department, Forestry Research Institute of Nigeria, P.M.B.5054, Jericho Hills, Ibadan, Oyo State, \\ Nigeria. \\ *Corresponding Author Email: ifebabs07@gmail.com; Tel: 08063381745
}

\begin{abstract}
There is urgent need to rescue Nigerian economy from deluge of crisis it is been confronted with at the present time. To achieve this, it is pivotal to explore various potentials available in the country to solve her problem. Therefore, this paper examines the potential of apiculture industry in social and economic development of the nation. Hive products such as beewax, propolis, pollen and royal jelly are known to have contributed largely to the economic development of advanced countries like China, Turkey, Mexico, Argentina, Hungary, Australia and Canada. While the practice provides job opportunities for people of all classes, it also boosts productivity of other agricultural crops.Honey from Nigeria will command higher demand and prices in the world market for its medicinal and antimicrobial qualities, thereby serving as a good foreign exchange commodity in international market. As part of its contribution to economic growth, apiculture is a good source of income for beekeepers, it involves the use of little land. It empowers small scale farmers and also does not damage the environment. The paper also stressed that apiculture is not only important for generating income, it also curbs against rural migration. Apiculture protects the environment and also an important non-timber forest product.
\end{abstract}

\section{DOI:https://dx.doi.org/10.4314/jasem.v25i9.2}

Copyright: Copyright (C) 2021 Agboolaet al. This is an open access article distributed under the Creative Commons Attribution License (CCL), which permits unrestricted use, distribution, and reproduction in any medium, provided the original work is properly cited.

Dates: Received: 09 May 2021; Revised: 12 August 2021; Accepted: 12September 2021

Keywords: Honey, Development, Nigerian economy, Agriculture, forest product

Apiculture also known as beekeeping is the management of bees in a hive in such a way as to observe its developmental stages and manipulations (Ojeleye, 1999). According to NHB (2004), beekeeping date back to around $2500 \mathrm{BC}$, when the first evidence appeared in the paintings of ancient Egyptian art. However, L. L. Langstroth is often referred to as the father of modern day beekeeping, when he developed the langstroth wooden hive in 1862 (Canon, 2003).Apiculture as a venture is relatively acceptable by people of all ages, gender, religion and class. It is comparatively cheap compared to other income generating activities (Islam et al., 2016). Beekeeping includes the collection and taking care of bees, pollination of field crops by bees, the study of bee product and the breeding of bee for honey production either in small or large scale. Beekeeping for honey production is a profitable agricultural enterprise nowadays in all parts of the world including Nigeria. It is an important foreign exchange earner for those that export honey and beeswax. Following the production trends, China is the number one honey exporter in the world, selling $\$ 246,550,000$ (12\% of total natural honey exports in the world) closely followed by Argentina with \$212,637,000 (10.3\%) and New Zealand at third $\$ 319,316,000(6.8 \%)$ (Ayansola, 2012), this shows how valuable this enterprise is especially in the countries where it has been embraced a long time and has been a source of revenue and export in these countries. Apiculture is a sustainable form of agriculture that can provide rural people with a source of much needed income and nutrition therefore they have economic reasons to retain the natural habitat or modify it to boost honey production because it has potentials to increase yield such as other agricultural products. Babatunde et al., (2007).In terms of potential economic contribution of beekeeping, Gidey and Mekonen (2010) have suggested that beekeeping is an environmentally friendly and non-farm business activity that has immense contribution to the economies of the society and to a national economy as a whole. Beekeeping generates products with high market potential, while being more easily adapted to constraints of low credit and limited land access than other agricultural activities Cristina and Molly (2015). In this regard beekeeping could be considered as a reliable source of alternative income. Verma, (1990) has argued that beekeeping can make a significant contribution to the economic upliftment of small and marginal farmers in terms of food and cash income, and gainful employment near home. Bekeeping can help economically vulnerable communities achieve economic stability. Honey production, pollination services, agriculture, and forestry are but a few of the economic benefits of beekeeping Ahamad et al; 
(2007).This study therefore seeks to examine the potentials of honeybee to social and economic development of the nation. As one of the countries in Africa, Nigeria has potential to boost her economy with earning from exportation of honey because honey from Nigeria will command higher demand and prices in the world market for its medicinal and antimicrobial qualities. It has been certified that honey from the tropics has special attractive aroma which is of higher quality to the ones from other parts of the world owing to diversity of plants from where honeybees visit for nectar and pollens collection (UNCTAD, 2006).Because of EU ban on Chinese honey due to identification of antibiotics in it, world honey market was adversely affected. China had been the largest exporter of honey to Europe before that time. This development brought about shortage of honey supply to Europe and honey prices increased rapidly (BBC News $12^{\text {th }}$ July, 2002). It is however unfortunate that Africa is yet to take advantage of this, despite the superior quality of African honey, it is still absent in EU honey importations. As reported by UNCTAD (2006), only African countries like Kenya, South Africa, Tanzania, Uganda and Zambia meet up with the requirement in the world market. Due to low little risk of contamination by chemical residue, the honey from Nigeria is of good quality and can attract higher prices in EU market. The price of honey in Nigeria ranges from $\$ 100,000$ - $\$ 120,000$ per ton. Therefore, if Nigeria were to export 2,000 tons of honey produced annually, the nation will make 200-240 million naira per year (Adediji and Omoba, 2016)

Honey;Honey is one of the most widely sought products due to its unique properties, which are attributed to the influence of the different groups of substances it contains Buba et al., (2013). The bees collect the sweet juices from various honey plants, process them in their digestive systems, and then store them in wax honeycombs, which are collected by beekeepers (Jovanovic, 2015).Honey is the natural sweet, viscous substance produced by honeybees from the nectar of blossoms or from the secretion of living parts of plants or excretions of plant sucking insects on the living parts of plants, which honeybees collect, transform and combine with specific substances of their own, store and leave in the honeycomb to ripe and mature. Honey is one of nature's wonders. Honey has been around for a long time and yet we know little about it. Honey has been a common sweetner for foods and a powerful medicinal tool for centuries. It is the simplest and often the best way to soothe a sore throat and can be taken at any time (Krell, 1996).Honey is a sweet food made by bees using nectar from flowers. The variety produced by honeybees (the genus Apis) is the most commonly referred to as it is the type of honey collected by most beekeepers and consumed by human (National Honey Board, 2012). Honey gets its sweetness from the monosaccharides fructose and glucose, and has approximately the same relative sweetness as that of granulated sugar (National Honey Board, 2012). Honey has attractive chemical properites for baking and a distinctive flavor that leads to some people to prefer it over sugar and other sweetness and most micro-organisms do not grow in honey because of its slow water activity of $0.6 \%$ Lansing et al, (1999).

Use of Honey:Honey's greatest medicinal potential is its application as topical agent to wounds and skin infections Carter et al, (2010). Honey has antiinflammatory, antioxidant and immune boosting properties. Much of thetheraupeutic properites of honey are due to high sugar concentration and the resulting osmotic effect Osato et al, (1999). Honey mixes well as a sweetner in hot and cold drinks. It goes with nearly all foods, the moisture absorbing quality of honey helps breads, cakes, cookies and candies stay fresh longer (MAAREC, 2004).Honey can help in children ailments like cough, diarrhea and bedwetting. Honey also helps to cure infertility and impotence, low libido. National medicinal products have been used for millennia in the treatment of multiple ailments. Although many have superseded by conventional pharmaceutical approaches, there is currently, resurgence in interest in the use of honey and honey products by the general public ManyiLoh et al, (2011).Honey is fed to diary cows to stimulate milk production. Similarly it is used in poultry and fish feeds. Honey is also used in the treatment of wounds, taking honey daily can help in protection against known and unkown ailments.Currently, honey is widely used for nourishment, constituting a nutritious supplement with medicinal properties recognized all over the world Montenegro et al., (2003); this has led to its current use in the treatment of a number of pathologies (Molan, 2001; Kahn etal; 2007). Because of its high nutritous value and unique flavor, honey has become increasingly accepted by consumers, often being used as a substitute for other sweetness Montenegro et al., (2003).

Lifecycle of Honeybees: The lifecycle of honey bees is divided into 4 stages: the egg, the larval, the pupal and the adult stages. The Queen bee lays about 200-3000 eggs in a day. The positioning of the egg is usually upright and falls on the side by the third day. Fertilized eggs develops into female bees or queen bees. Unfertilized eggs hatches into the male bees also known as drone bees. The difference between a worker and the queen bee is made three days after the egg transforms into larvae and six days after the egg is laid 
in the beehive.In pupal stage, the bee has developed parts i.e the eyes, legs, wings and body.Once the pupa is matured, the new adult chews its way out of the closed cell. The queen bee takes about 16 days from egg stage to form an adult, worker bee takes 18-22days while drone bee takes 24 days to develop into an adult bee.

\section{Other by-products of honeybees \\ * Pollen \\ * Propolis \\ \# Royal Jelly}

\section{Minor Products; \\ * Bee brood \\ \# Bee venom}

Bee pollen is derived from the joining of flower pollens with nectar and salivary substances of the honeybees (Apis melifera) Pascoal et al.,(2013). Bee pollen is used in the hive to feed the bees in all their stages of development. In particular the particles of pollen constitute the most significant source of proteins to guarantee the survival of bees. Almeida Muridian et al, (2005). Bee pollen constitute one of nature's most complete and nutritious foods because it gathers almost all nutrients necessary for humans. Bee pollen is a complete sustenance and contains many components not found in foods from animal origins.Propolis is a natural resinous mixture produced by honeybees from substances collected from parts of plants, buds and exudates. The word propolis is derived from Greek, in which pro stands for "at the entrance to" and polis for "community" or "city" which means this natural product is used in hive defense. Another name for propolis is bee glue. Due to its waxy nature and mechanical properties, bees use propolis in the construction and repair of hives, for sealing opening and cracks and smoothing out the internal walls (Burdrock, 1998). The many active properties in propolis gives it really remarkable properties in combating all types of pathogens (bacteria, viruses, parasites and fungi) and was used as a health drink in various Asian, European and American countries Banskota et al, (2001). Royal Jelly is a substance of complex chemical structure produced by the young nurse bees as larva food. Although it is not quite as well known as bee pollen, royal jelly equals pollen in its salutary effects. Without royal jelly, queen bees would fail to develop properly. Royal jelly is a thick, extremely nutritious, milky-white, creamy liquid secreted by the hypo-pharyngeal glands of the nurse bees.

Contributions of Apiculture (beekeeping) to social and Economic development of the Nation: Apiculture has a strong potential to contribute to the economy of many countries. Beekeeping has helped in the pollination of a large range of crops. Honey a major product gotten from bee keeping has been used for ages in so many foods and also a major constituent of some food products.

* Honey is an important non-timber forest product.

* Bees pollinate numerous species of plants, thus contributing immensely to agricultural production and the conservation of biological diversity.

* Beekeeping is a good source of income and it does not damage the environment.

* Beehive crops serves as a raw material to industries like pharmaceuticals, confectionaries, tobacco, breweries.

* The practice of beekeeping requires the use of little land.

* Bee keeping is not rigorous or labour intensive.

* It empowers small scale farmers.

* It does not compete with other agricultural enterprises for land or space.

* It is an important occupation and a component of rural life.

* Beekeeping provides honey as a source of food and acts as source of income for beekeepers.

Conclusion: Apiculture industry has the potentials of giving people opportunities for reliable income generation either through exporting or job creation. Bee-keeping generates rural employment and also curbs against rural migration. Apiculture requires the use of little land, helps in pollination of plants and does not damage the environment. Apiculture could be one of the strong pillars for reducing poverty, economic vulnerability, especially in developing countries and low-income regions. There is therefore great advocate for it to be embraced by stakeholders and government at all level as one of the ways to boost the economy of Nigeria when it is adequately explored.

\section{REFERENCES}

Adediji, N.K. and Omoba, O.J. (2016). An assessment of profitability of honey production in Edo State, Nigeria. Afr. J. Agric. Econ. Rural Develop.4(6): 442-445

Ahmad, F; Gurung, M.B; Joshi, SR; (2007).Beekeeping and Rural Development, International Centre for Integrated Mountain Development

Ameida - Muradian, LB; Pamplona, LC; Coimbra, S; Barth, OM (2005). Chemical Composition and 
botanical evaluation of dried bee pollen pellets. $J$. Food compos. Analysis 2005; 18:105-11

Ayansola, AA (2012).An appraisal of Apicultural Practices in South Western Nigeria. J. Agric. Sci. 3(2) $79-84$

Babatunde, RO; Olorunsanya, EO; Omotesho, OA; Alao, BI (2007), Economics of Honey Production in Nigeria: Implications for Poverty Reduction and Rural Development. GAEP 3(2) Pp 23-29

Banskota, AH; Tezuka,Y; Kodota, S (2001).Recent progress in pharmacological research of Propolis. Phytotherapy Res., 15:561-71

BBC News, Friday, $12^{\text {th }}$ of July, 2002, Nicola Carslaw, BBC Consumer affairs Correspondent in China

Buba, F., Gidado, A., Shugaba, A. (2013). Analysis of Biochemical Composition of Honey Samples from North-East Nigeria. Biochem Anal Biochem 2: 139. doi: 10.4172/2161-1009.1000139

Burdock, GA (1998) "Review of the biological properties and toxicity of bee propolis (Propoles)," Food. Chem. Toxic. 36 (4). 347 - 363, 1998

Carron, D (2003): Bees for Development. Bes culture Journal, 21: 11-12

Carter, DA; Blair, SE; Irish, J (2010). An investigation into the Therapeutic Properties of Honey: Rural Industries Research and Development Corporation, Sydney

Cristina, BP; Molly, MD (2015). Women, Apiculture and Development; Evaluating the impact of a Beekeeping Project on Rural Women's livelihoods. Bulletin VASVM Horticullture 72(2)

Gidey, Y; Mekonen, T (2010). Participatory Technology and Constraints Assessment to improve the livelihood of Beekeepers in Tigray Region, Northern Ethiopia, Middle East J. Sci. 2(1), 76 - 92

Islam, M.R. Chhay, L., Milan, M.M. and Nasry, N.B. (2016). The financial analysis of apiculture profitability in Bangladesh. Asian J. Agric.Exten. Econ. Soc.9(2): 1-8

Jovanović, N. (2015). Antimikrobna i antioksidativna aktivnost različitih uzoraka meda iz okoline Niša, Magistersi rad. Prirodno matematicki fakultet Niš, Univerzitet u Niš.

Khan, FR; Abadin, Z UI; Rauf N (2007). Honey nutritional and medicinal value. Inter.J. Clinical Practice 61:1705 - 1707
Krell, R (1996) Value added products from beekeeping, Rome: FAO

Lansing, AE; Ivnik, RJ, Cullum, CM; Randolph, C (1999): An empirically derived short from of the Boston Naming Test, Achives of Clinical Neuropsychology:14, 481-487

Manyi-Loh, CE; Clarke, AM; Ndip, RN (2011). An overview of honey: Theraupetic properties and contribution in Nutrition and human health. Afr J.Microbiol. Res. 5:844-852

Mid-Atlantic Research \& Extension Consortium (MAAREC) (2004) HONEY. New Jersey

Molan, PC (2001). Why honey is effective as a medicine 2. The scientific explanation of its effects. Bee World 82:22-40

Montenegro, RG; Salas, F; Pena, RC; Pizarro, R (2009). Actividad antibacteriana y antifungica de mieles monoflorales de Quillajasaponaria, especie endemic de chile, dyton 78:141-146

National Honey Board (2012): Carbohydrates and the sweetness of honey (http:///honey.com/omages/downloads /carb.pdf) Langing

NHB (2004): "The Story of Honey". National Honey Board, Longmont Colorado.www.nhb.org

Ojeleye, B (1999): Foundations of Beekeeping in the Tropics. Centre for Bee Research and Development (CEBRAD) Press, Ibadan, Nigeria. Pp 325

Osato, MS; Redy, SG; Graham, DY (1999) Osmotic effect of honey on growth and viability of Helicobacter Pylori. Dig Dis. Sci. 44:462-464

Pascoal, A; Rodrigues, S; Teixeira, A; Feas, X; Estevinho, LM (2014). Biological activities of commercial bee pollens. Anti-microbial, artimutagenic, antioxidant and anti-infammatoryFood Chem. Toxic. 2014: 63:233-9

United Nations Conference on Trade and Development 'UNCTAD (2006). The African Honey Trade: Unlocking the Potential by Bees for Development, Troy, Monmouth, U.K

Verma, R (1990). Beekeeping in Integrated Mountain Development: Economic and Scientific Perspectives. Oxford and IBH, New Delhi. Available at http://lib. icimod.org/ record/25732/ files/c_attachment_468_3721. Accessed May 19, 2017. Worku Abehaw Asressie, (2012). Bees for Development Journal 95. 